Urban History, 44, 3 (2017) (C) Cambridge University Press 2016. This is an Open Access article, distributed under the terms of the Creative Commons Attribution licence (http:// creativecommons.org/licenses/by/4.0/), which permits unrestricted re-use, distribution, and reproduction in any medium, provided the original work is properly cited. doi:10.1017/S0963926816000377

First published online 22 August 2016

\title{
Health, wealth and party in inter-war London
}

\author{
JANE K. SEYMOUR, MARTIN GORSKY \\ and SHAKOOR HAJAT* \\ Department of Social and Environmental Health Research, London School of \\ Hygiene and Tropical Medicine, 15-17 Tavistock Place, London WC1H 9SH, UK
}

\begin{abstract}
This article examines public health spending, health outcomes and political complexion in London's 28 Metropolitan Borough Councils (MBCs) in the inter-war period. It describes the place of the MBCs in the governance of the capital and demonstrates the variety of experience across the different boroughs in terms of wealth, politics and mortality. Searching for potential causes of differences in outcomes, it discovers some positive statistical relationships between the extent of Labour party presence on the councils, local spending and health outcomes. Our tentative conclusion is that local democratic processes could lead to distinctive and beneficial public health policies, albeit within the context of other local and structural determining factors.
\end{abstract}

For scholars of public health, inter-war Britain provides an historical locus classicus of a decentralized system. ${ }^{1}$ In this period, only health insurance was subject to a national standard, following the Act of 1911 that introduced mandatory coverage for specified categories of worker. Otherwise, public health and related social welfare powers were assigned to different local bodies, according to the cumulative effect of legislation over several centuries. ${ }^{2}$ In the 1920s, such bodies included the Poor Law Unions, which provided medical and social care in hospitals and mixed institutions (originally 'workhouses'). There were also district,

\footnotetext{
* We thank Virginia Berridge, Karen Lock, Becky Taylor and two anonymous referees for helpful advice on this article. An early version was presented at the Society for the Social History of Medicine Conference, Oxford, June 2014, and we are grateful to participants for comments. Seymour's research was undertaken under a Wellcome Trust Library Fellowship, Grant ref: WT 099835, and we thank the Trust for its support.

1 J.M. Dunlop, 'Social policy devolution: a historical review of Canada, the United Kingdom, and the United States (1834-1999)', Social Work in Public Health, 24 (2009), 191-209; A. Levene, M. Powell, J. Stewart and B. Taylor, Cradle to Grave: Municipal Medicine in Interwar England and Wales (Oxford, 2011);J. Welshman, Municipal Medicine: Public Health in Twentieth-Century Britain (Oxford, 2000).

2 B. Harris, The Origins of the British Welfare State: Social Welfare in England and Wales, 1800-1945 (Basingstoke, 2004).
} 
county borough and county councils, which had been created in 1888 as basic units of local government, with duties covering education, policing and infrastructure. Their early public health responsibilities had been principally environmental, focused on water, sanitation and hygiene, but subsequently broadened to include the institutional and curative. In 1929, the Poor Law Unions were dissolved, their duties allocated to local government and managed either through public health or public assistance committees. With funding largely from local taxation - the 'rates' - and with regular elections holding councils accountable to voters, interwar Britain offers valuable evidence of the functioning of a health polity premised on localism.

Policy debate about whether decentralized health services are appropriate to meet national goals has developed through the twentieth century. ${ }^{3}$ The trend since 1900 in Britain had been towards concentration of health powers at the centre, first through channelling increased state funding towards local government, then through the establishment of the National Health Service (NHS). The political justification given by Aneurin Bevan, the NHS's founder, was that localism was by its nature too uneven to ensure sufficient equity of access and quality: 'if it be our intention that we should universalize the best... how can that be articulated through a rate-borne institution which means that the poor authority will not be able to carry out the same thing?'. ${ }^{4}$ Greater state control and newly created special authorities were therefore required. Early historians accepted this. The sanitarian issues which had originally necessitated a localist health politics were effectively solved; now, changing 'social ideas' meant that locally determined poor relief had been superseded by a positive notion of public benefits, delivered to a common standard. ${ }^{5}$

However, a counter argument emerged during the NHS debates, voiced by the Labour politician Herbert Morrison, who drew on his experience leading the London County Council (LCC). ${ }^{6}$ He urged that local interventions could be more responsive to citizens because they addressed preferences directly expressed in council elections. ${ }^{7}$ They could also be more effective than central fiat in meeting collective goals, as the LCC health department had demonstrated. Following Morrison's defeat in cabinet by Bevan, the pro-localist argument lost momentum.

3 A. Mills, 'Decentralization and accountability in the health sector from an international perspective: what are the choices?', Public Administration and Development, 14 (1994), 28192; C. Collins and A. Green, 'Decentralization and primary health care: some negative implications in developing countries', International Journal of Health Services, 24 (1994), 45975.

${ }^{4}$ A. Bevan, National Health Service Bill, second reading, Parliamentary Debates (Hansard) 5th Series, vol. 422, col. 49 .

${ }^{5}$ A.T. Peacock and J. Wiseman, The Growth of Public Expenditure in the United Kingdom (Princeton, 1961), 117-20.

6 R. Klein, The New Politics of the NHS. From Creation to Reinvention (Oxford, 2006), 12-21.

7 The National Archives (TNA), CAB/129/3, memorandum by the Lord President of the Council, 'The future of the hospital service', 16 Oct. 1945. 
Concern about democratic deficit then began to resurface from the 1970 s as friction arose between the emergent patient consumer and the bureaucratic character of NHS medicine. ${ }^{8}$ The policy response was changing permutations of community or 'patient and public' involvement, and, since 1989, the internal market, whose purchasing functions aimed to express local needs by proxy. ${ }^{9}$ More recently, explicitly Morrisonian ideas were resurrected to justify the 2012 return of the public health function to local government. ${ }^{10}$ Grassroots wishes could feed into policy through the electoral process, and the national goal of narrowing health inequalities could be met by integrating health into policy areas such as environment or education.

Historical evaluation of local government health policy in Britain before the NHS therefore addresses two overarching questions. Was it the case that variations in the resource base and administrative capacity led to a sub-optimal position - the Bevan argument? Or did the growing range of services described above, coupled with the disciplines of the local ballot box, provide a viable model of health system development - the Morrison claim? In this article, we report results of research into these issues in London. We focus on Britain's capital partly to redress its neglect in recent historical appraisals of inter-war health care. Our view is that its size, importance and proximity to national government should place it at the heart of analysis. We are mindful too of the digitization by the Wellcome Trust of all London's borough medical officer of health reports, whose electronic availability now privileges the metropolis as site of historical investigation. ${ }^{11}$ A secondary purpose of our study is to provide essential contextual detail against which these sources can be interrogated.

We begin by outlining the recent historiography surrounding inter-war municipal health care. We then describe our sources and methods, and discuss the complexities of London as a case-study, with its different layers of health service administration. The central section presents descriptive statistics of health, wealth and political affiliation in the metropolitan boroughs, the city's meso-level tier of local government. We conclude by examining the relationships between these variables to discover whether they illuminate the questions posed by the Bevan/Morrison debate.

${ }^{8}$ R. Klein and B. New, Two Cheers? Reflections on the Health of NHS Democracy (London, 1998); A. Mold, Making the Patient-Consumer. Patient Organisations and Health Consumerism in Britain (Manchester, 2015).

${ }^{9}$ T. Milewa, J. Valentine and M. Calnan, 'Managerialism and active citizenship in Britain's reformed health service: power and community in an era of decentralisation', Social Science Medicine, 47 (1998), 507-17.

10 M. Gorsky, K. Lock and S. Hogarth, 'Public health and English local government: historical perspectives on the impact of "returning home"', Journal of Public Health, 36 (2014), 546-51.

11 Wellcome Library, 'London's Pulse: medical officer of health reports 1848-1972', http:/ / wellcomelibrary.org/moh/\# accessed 25 May 2015. 


\section{Contexts}

Hitherto, debate about inter-war localism has focused on two areas, the demographic and the political. The first of these turns principally on what trends in population health reveal about the functioning of the health system. This was the era of mortality transition, and while there has been extensive debate about the contribution of public health intervention to this, it seems clear that it played at least some part. ${ }^{12}$ If local agency mattered, then the question arose of how well it had met the needs generated in the 'hungry thirties'. One line of argument holds that the accentuated regional disparities across indicators of illness and death during this period illustrate the failure of localist social and economic policy. ${ }^{13}$ The counter claim, now broadly ascendant, is that although a clear social gradient obtained in mortality statistics, which mapped onto geographies of wealth, these variations did not unduly worsen, and the long-term pattern remained one of improvement. ${ }^{14}$ This is attributed to the proto-welfare state, including both national insurance and local health, housing and benefit strategies.

The second, and closely related, area of historiographical debate concerns the political effectiveness of public health in local government. ${ }^{15}$ Early commentators, often medical professionals, took a whiggish view. For them, the empowerment of public health officers was the enlightened incorporation of scientific wisdom into social administration. ${ }^{16}$ Indeed, the inter-war period was a 'golden age' for the local authority medical officer of health (MOH), who controlled a wide gamut of environmental and clinical services. A more critical history arose by the 1980s, which argued that the seeds of public health's later marginalization were sown in this period. ${ }^{17}$ The modest status of the specialty attracted bureaucratic and cautious recruits, and $\mathrm{MOH}$ s were overstretched by new duties of clinical administration. The result was that preventive medicine lost momentum and rather than being 'watchdogs' of the poor, MOHs became 'lapdogs'

12 J. Colgrove, 'The McKeown thesis: a historical controversy and its enduring influence', American Journal of Public Health, 92 (2002), 725-9; B. Harris, 'Public health, nutrition and the decline of mortality: the McKeown thesis revisited', Social History of Medicine, 17 (2004), 379-407.

${ }^{13} \mathrm{C}$. Webster, 'Health, welfare and unemployment during the depression', Past and Present, 109 (1985), 204-30.

14 P. Congdon and H. Southall, 'Small area variations in infant mortality in England and Wales in the inter-war period and their link with socio-economic factors', Health and Place, 10 (2004), 363-82.

${ }^{15}$ M. Gorsky, 'Public health in interwar England and Wales: did it fail?', Dynamis, 28 (2008), 175-98.

16 J. Harley Williams, A Century of Public Health in Britain 1832-1929 (London, 1932).

17 J. Lewis, What Price Community Medicine? The Philosophy, Practice and Politics of Public Health since 1919 (Brighton, 1986). 
of the establishment, acquiescing with austerity policies during the slump despite their detrimental effect on welfare services. ${ }^{18}$

In the last 20 years, this revisionism has itself come under scrutiny, leading to a more mixed verdict. Better awareness of the scientific uncertainties over nutrition and health status now caution against condemning inactive $\mathrm{MOH}$ as quiescent. ${ }^{19}$ Case-studies of individual boroughs have discovered energy and innovation. ${ }^{20}$ Detailed qualitative work on tuberculosis suggests that places with more active policies were most successful in driving down mortality. ${ }^{21}$ Studies of hospital improvement similarly emphasize variation, between places where officials and councillors made positive attempts to shed Poor Law trappings, and other less progressive locations. ${ }^{22}$ There is also evidence that services which did remain within the Poor Law/public assistance ambit, notably long-stay infirmaries, were left behind in the general service development of the period. ${ }^{23}$

Comparative analysis of spending and service patterns in the county boroughs (the largest provincial cities) has sharpened understanding of this spatial unevenness. Here, the premise is that financial data offers a proxy for activity, and thus permits comparison between places. ${ }^{24} \mathrm{On}$ the one hand, this has underscored Bevan's contention that the local economy and tax base ultimately determined spending capacity. ${ }^{25}$ Given that populations in poorer locations had worse health and thus higher needs, this provided evidence for an 'inverse care law'. However, within this framework, some variations in expenditure could legitimately be interpreted as 'investment choices', made either in response to local wishes, or through individual actors who galvanized change. ${ }^{26}$ Tests of the

18 C. Webster, 'Healthy or hungry thirties?', History Workshop Journal, 13 (1982), 110-29; C. Webster, 'Medical officers of health - for the record', Radical Community Medicine (Autumn 1986), 10-14.

19 J.K. Seymour, 'Citizenship, the state and the chief medical officer: Sir George Newman and interwar health policy', University of London Ph.D. thesis, 2012.

${ }^{20}$ J. Welshman, 'The medical officer of health in England and Wales, 1900-1974: watchdog or lapdog?', Journal of Public Health Medicine, 19 (1997), 443-50; M. Gorsky, 'The Gloucestershire Extension of Medical Services Scheme: an experiment in the integration of health services in Britain before the NHS', Medical History, 50 (2006), 491-512.

${ }^{21}$ S. Bowden and A.T.C. Sadler, 'Getting it right? Lessons from the interwar years on pulmonary tuberculosis control in England and Wales', Medical History, 59 (2015), 10135.

22 A. Levene, M. Powell and J. Stewart, 'The development of municipal general hospitals in English county boroughs in the 1930s', Medical History, 50 (2006), 3-28; J. Neville, 'Explaining local authority choices on public hospital provision in the 1930s: a public policy hypothesis', Medical History, 56 (2012), 48-71.

23 A. Levene, 'Between less eligibility and the NHS: the changing place of Poor Law hospitals in England and Wales, 1929-39', Twentieth Century British History, 20 (2009), 322-45, at 339.

24 A. Levene, M. Powell and J. Stewart, 'Patterns of municipal health expenditure in interwar England and Wales', Bulletin of the History of Medicine, 78 (2004), 635-69.

25 R. Lee, 'Uneven zenith: towards a geography of the high period of municipal medicine in England and Wales', Journal of Historical Geography, 14 (1988), 260-80.

26 A. Levene, M. Powell and J. Stewart, 'Investment choices? County borough health expenditure in inter-war England and Wales', Urban History, 32 (2005), 434-58. 
relationship between spending patterns and party politics again produced contradictory results: there was some evidence that Labour boroughs prioritized maternal and child welfare policies, but municipal hospital improvement might equally be championed by Tories alert to the objectives of their national leadership. ${ }^{27}$

London has attracted some attention in this debate, although it has not yet been subject to quantitative analysis of expenditure and activity. Early histories written in the register of 'record of achievement' celebrated the LCC as 'probably the finest municipal hospital service in the world' and documented the extent of its empire. ${ }^{28}$ Subsequent studies emphasized the influence of Labour politics, particularly the ideas of the Socialist Medical Association, operating through Somerville Hastings as chair of the LCC's Health and Medical Services Committee. ${ }^{29}$ The complexities of London's pluralist provision, with municipal innovation in different fields, alongside the many voluntary hospitals and medical charities, raised questions about system integration. ${ }^{30}$ In the hospital arena, some friction existed between the King's Fund, which gave voice to the voluntary hospitals, and the LCC, which saw its mission as addressing hitherto unmet needs, yet both sectors contributed to a major augmentation of provision. These factors, alongside the declining infant mortality rate, have prompted standard texts on London to observe a 'heartening trend' in health gains. ${ }^{31}$

In sum, ongoing studies of the devolved health system have not provided a definitive vindication of either the Bevanite or Morrisonian position. We now understand better that Bevan's centralization was as much pragmatic politics as technocratic preference, a response to the unwillingness of various interest groups in the policy debates of 1944-46 to accept a local government-led NHS. ${ }^{32}$ However, the evidence accumulated since continues to support his argument for the diversity of performance across places. Yet, at the same time, the possibilities of local choice and the creative agency of local actors have modified claims for the inter-war years as the nadir of public health.

${ }^{27}$ M. Powell, 'Did politics matter? Municipal public health expenditure in the 1930s', Urban History, 22 (1995), 360-79; Neville, 'Explaining local authority choices'.

28 W.E. Jackson, Achievement. A Short History of the London County Council (London, 1965), 25.

${ }^{29}$ J. Stewart, "'For a healthy London": the Socialist Medical Association and the London County Council in the 1930'', Medical History, 41 (1997), 417-36.

30 E. Lebas, "When every street became a cinema". The film work of Bermondsey Borough Council's public health department, 1923-1953', History Workshop Journal, 39 (1995), 42-66; M. Gorsky and J. Mohan, 'London's voluntary hospitals in the interwar period: growth, transformation, or crisis?', Nonprofit and Voluntary Sector Quarterly, 30 (2001), 249-79.

$31 \mathrm{~J}$. White, London in the Twentieth Century (London, 2008), 232; S. Inwood, A History of London (London, 1998), 734.

32 J. Stewart, 'Ideology and process in the creation of the British National Health Service', Journal of Policy History, 14 (2002), 113-34. 


\section{Research questions and sources}

Our aim in this article is to contribute to the above debate through a quantitative analysis of inter-war health spending and its determinants in London's metropolitan boroughs. These formed the tier of local government beneath the LCC, which, despite not having such broad powers as the provincial county boroughs, also undertook a range of public health duties. We will first clarify what these were. We will then examine the differences between the boroughs with respect to the main health indicators and consider, at a descriptive level, the relationship between these and underlying wealth. Next we will turn to local politics, clarifying the boroughs' changing political complexion in a period marked by the forward electoral march of the Labour party. These data lay the groundwork for a consideration of variations in health expenditure, and again we will use descriptive statistics to characterize differences in activity across space and time. Finally, we will conduct correlation and regression analysis to explore the relationships, if any, between the variables of expenditure, wealth, politics and health outcomes.

The sources we use and indicators we derive are as follows. Population health data for the metropolitan boroughs are taken from the RegistrarGeneral's Annual Reports and the electoral data are taken from Willis and Woollard's compilation of twentieth-century local election results. ${ }^{33}$ Expenditure and wealth data come from the Local Taxation Returns (LTR), later the Local Government Financial Statistics (LGFS) for data on metropolitan borough council (MBC) spending. ${ }^{34}$

To compare data between MBCs, we have grouped into four main categories spending classed as 'public health' under the MOH's department. 'Environmental' expenditure refers to sewerage and refuse disposal; 'clinical' to programmes or institutions addressing tuberculosis and venereal disease and maternal and child welfare; 'preventive' to vaccination schemes, food and drug safety and community approaches to infectious disease, such as notification and local disinfection; and 'amenities' to baths, washhouses, public conveniences, parks and open spaces. In addition, the housing budget is shown. It should be borne in mind that a borough's geography and infrastructural inheritance would to some extent determine local spending priorities. ${ }^{35}$ Physical and demographic characteristics, such as size, proximity to the river or major railway termini, availability of open spaces, type and age of housing stock, as well as industry and patterns of employment, all had an

33 A. Willis and J. Woollard, 20th Century Local Election Results, vol. I: Election Results for the London County Council (1889-1961) and London Metropolitan Boroughs (1900-1928), vol. II: Election Results for London Metropolitan Boroughs (1931-1962) (Plymouth, 2003).

34 B. Brocks, 'Statistics available on the local government services', Journal of the Royal Statistical Society, 118 (1955), 234-44.

${ }^{35}$ Levene, Powell, Stewart and Taylor, Cradle to Grave. 
impact on local needs and opportunities which in turn structured political choices. ${ }^{36}$

Rather than comparing change between single years, our strategy is to calculate mean experience over periods of several years, to avoid any annual extremes that might obscure trends. Where figures are shown per capita, these are based on population data recorded annually in the LTR/LGFS. Finally, we have excluded from our calculations the City of London due to its anomalous status as a business district governed by an ancient corporation that was not an MBC. Its fixed population was disproportionately tiny (in 1922/23 only 13,650 against an MBC mean of 161,682$)$, while its rateable value was far higher $(£ 6,452,777$, mean $£ 1,535,441)$ and some categories of public health spending were trivial or non-existent. Exclusion removes its distorting effect.

\section{Metropolitan boroughs in context}

There are both practical and conceptual difficulties involved in the comparative analysis of public health in local government, which have exposed earlier scholars to criticism. ${ }^{37}$ First, the sources collated nationally provide only a partial picture of overall activity. In the county boroughs for example, the LTR and LGFS contain comprehensive income and expenditure statistics of inter-war public health departments, disaggregated into the categories mentioned above. However, a substantial record of local action was also subsumed under education spending, which funded much of the school medical service and child health facilities, and the Poor Law/public assistance budgets, which were particularly important in mental hospital funding, but also ranged across other areas including tuberculosis (TB) and domiciliary care. These medical portions of other budgets are only retrievable by consulting treasurers' abstracts for individual boroughs, which is obviously impractical in a large comparative sample. Nonetheless, it is misleading to represent without qualification the LTR/LGFS statistics as capturing 'municipal health expenditure'. ${ }^{38}$

A related problem concerns the selection of local government activities which may be classified as 'public health'. One approach is to include only the clinical work of public health departments: TB care, maternal and child health, mental health, general and isolation hospitals, vaccination programmes and sexual health clinics. This assumes that the impact of environmental interventions was effectively complete by the inter-war period, and that because the curative services ultimately fell under the NHS it is they that merit attention. ${ }^{39}$ More convincingly, others assume

36 TNA, MH 66 /1080-4, Public Health Survey Reports: Metropolitan Boroughs.

${ }^{37} \mathrm{M}$. Gorsky, 'Local government health services in interwar England: problems of quantification and interpretation', Bulletin of the History of Medicine, 85 (2011), 384-412.

38 For example, Levene, Powell and Stewart, 'Patterns of municipal health expenditure'; Levene, Powell and Stewart, 'Investment choices?'.

39 Levene, Powell and Stewart, 'Patterns of municipal health expenditure'. 
that a wide gamut of action affected health outcomes and must therefore be considered, so that preventive environmental services, housing policy and social care also constitute 'municipal medicine' ${ }^{40}$

It is important therefore to specify the variables which have been chosen and the trade-offs involved in relying on the LTR/LGFS. These yield only a partial picture and any conclusions about spatial variation or health impacts are tempered by these limitations. This is particularly so in the case of London, where in addition to the schools and public assistance budgets, substantial activity lay in the remit of the LCC, and cannot be mapped onto the geography of the MBCs. We will briefly describe these, after bringing into view the health work of the MBCs.

London's inter-war MBCs had been created by the London Government Act of 1899. Their birth shortly followed that of the LCC (1888), whose accrual of power sparked calls for a lower tier to represent localist concerns hitherto articulated at vestry level. ${ }^{41}$ As sanitary authorities, the MBCs' public health responsibilities spanned environmental services (sewers, refuse) and amenities (public baths and conveniences, parks), food safety (inspections, bacteriological analysis), control of infectious diseases (notification, disinfection, isolation), housing (inspection, new building) and some clinical services, though not hospitals. After the 1929 Local Government Act (LGA) they also took over responsibility for vaccinations from the Poor Law. In our period, each MBC had an $\mathrm{MOH}$ heading its health department, along with assistant medical officers, sanitary inspectors, analysts, health visitors and, in some places, dental staff, 'propaganda' officers and so on.

The first complicating factor is that, as elsewhere, the Poor Law authorities also exercised various health functions before 1929. Historically these were: domiciliary 'out-relief', including the services of a medical officer; civil registration; vaccination programmes and the workhouse infirmaries which disproportionately housed the 'chronic' sick and infirm excluded from voluntary hospital care. ${ }^{42}$ In London, a city-wide Poor Law body, the Metropolitan Asylums Board (MAB), had been established in 1867 following concern at the quality of workhouse care, and this controlled infectious diseases hospitals, institutions for epileptics and the 'feeble-minded' and TB dispensaries. ${ }^{43}$ By the time of the transfer of Poor Law functions in 1930, when the LGA came into force, the MAB's work also included an ambulance service, pathology laboratories and the education of trainee doctors. ${ }^{44}$

40 Welshman, Municipal Medicine.

41 J. Davis, Reforming London. The London Government Problem 1855-1900 (Oxford, 1988), 176247; K. Young and P. Garside, Politics and Urban Change 1837-1981 (London, 1982), 64-101.

42 K.B. Smellie, A History of Local Government, 4th edn (London, 1968), 64.

43 G.M. Ayers, England's First State Hospitals and the Metropolitan Asylums Board, 1867-1930 (London, 1971).

44 Ibid.; London County Council, The L.C.C. Hospitals: A Retrospect (London, 1949). 
The second area of health spending absent from both the London and provincial borough accounts in the LTR/LGFS was that of the education service. The London Education Act of 1903 conferred on the LCC responsibility for schools and hence for London's School Medical Service (SMS), when it was created in $1907 .{ }^{45}$ The county medical officer (CMO) also became London's school medical officer, and by 1939, his SMS empire included 20 doctors and 420 nurses carrying out inspection and treatment, open-air schools, TB schools, special schools and homes for disabled children, and provision for free school meals and subsidized milk. $^{46}$

Where London MBCs differed substantially from other English boroughs was in the overlapping powers delegated to the county authority. The LCC had been created after a long-running campaign for municipal reform. ${ }^{47}$ It inherited a city-wide environmental health remit from its predecessor, the Metropolitan Board of Works, including maintenance of the main drainage system, street improvements and oversight of building regulations and parks and open spaces. ${ }^{48}$ Its health department was headed by the CMO, whose duties also covered collation of vital statistics, and, by the 1920s, limited clinical services such as TB provision and midwife training. ${ }^{49}$

The 1929 LGA brought a more far-reaching extension of LCC powers, when it delivered the stock of the MAB and the Boards of Guardians, including 74 hospitals, of which 28 were Poor Law infirmaries, 14 infectious diseases hospitals and 9 TB hospitals or sanatoria, containing about 41,000 beds, in April 1930. ${ }^{50}$ The MAB hospitals passed to the control of the LCC's Public Health Committee, while 14 of the ex-workhouses fell to the Public Assistance Committee for social care. ${ }^{51}$ Eager to shed Poor Law trappings, the LCC's new municipal hospitals were opened to all, free from the 'old doctrine of deterrence' ${ }^{52}$ In addition, it scaled up London's ambulance service, removed fees for TB sanatoria and opened the Hammersmith postgraduate medical school. ${ }^{53}$ Here was the source of the 'finest ... in the world' boast. ${ }^{54}$

45 S. Maclure, A History of Education in London 1870-1990 (London, 1990), 77-87.

46 Ibid., 99-101.

47 Davis, Reforming London; Young and Garside, Politics and Urban Change.

48 'The London County Council and the need for a County Hall', in Survey of London Monograph 17, County Hall, ed. Hermione Hobhouse (London, 1991), 1-5, www. british-history.ac.uk/survey-london/bk17/pp1--5 accessed 9 Jun. 2015.

49 G. Gibbon and R. Bell, History of the London County Council 1889-1939 (London, 1939), 288-362; Jackson, Achievement, 24.

50 J. Sheldrake, 'The LCC hospital service', in A. Saint (ed.), Politics and the People of London: London County Council 1889-1965 (London, 1989), 187-97.

51 TNA, MH 66/1080, Survey of the Public Health Services of the London County Council, $20-4$.

52 Gibbon and Bell, History of the London County Council, 407-8.

53 Jackson, Achievement, 24-5; B. Barker, Labour in London. A Study of Municipal Achievement (London, 1946), 147.

54 Jackson, Achievement, 25. 
Thus, despite the creation of the MBCs to take forward a localist agenda, this concurrent expansion of LCC powers created overlap and confusion in public health. 'There is no clear principle regulating the distribution of powers and duties between [the LCC] and the Borough Councils', observed a Ministry of Health official in 1930. ${ }^{55}$ Both the LCC and MBCs owned and managed parks and outdoor spaces. Both had charge of sewerage and drainage, with the LCC nominally in charge of main drains and sewers but also active in storm relief and treatment. ${ }^{56}$ Both had housing development powers, with 'no hard-and-fast rules' demarcating responsibilities. ${ }^{57}$ Broadly, the LCC took on the major slum clearance and rehousing schemes, and the MBCs the more modest ones, so that for example in 1934-39 the county built 30,455 new flats and houses, and the boroughs $10,890 .{ }^{58}$ Finally, both had TB powers, the LCC providing residential care and a percentage grant to support local MBC out-patient dispensaries. ${ }^{59}$

As in all borough-level analysis then, the MBC public health activities considered below provide an incomplete picture. There are no available figures to break down LCC or pre-1929 MAB spending by borough, which means we are unable to account for services such as the SMS and municipal hospitals. Another major lacuna in both provincial and metropolitan studies is the sums spent by charitable organizations and voluntary hospitals. While the expenditure of the latter can be derived from the King's Fund's statistical reports, their catchment areas cannot realistically be aligned with borough boundaries. Nor are collated data available on community-based health charities, which despite their importance are only visible in close archival research. ${ }^{60}$ This is a significant limitation, because the prior existence of alternative provision could affect expenditure priorities. ${ }^{61}$ In both Chelsea and Hampstead, for instance, voluntary societies provided all maternity and child welfare clinics and staffing, partially funded by grants from their respective MBCs, who preferred to contract rather than furnish their own public services. ${ }^{62}$

In light of these gaps, Table 1 conveys an approximate sense of the MBCs' proportionate contribution to health expenditure. It presents Londonwide comparative data from 1931-32, the first full financial year after the implementation of the LGA. Absent here are the smaller maternal and infant health charities, however, and it should be noted that to avoid double-counting in the voluntary hospitals total, grants received from

55 TNA, MH66/1080, Survey of Public Health Services, 1.

56 Jackson, Achievement, 14-15.

57 Gibbon and Bell, History of the London County Council, 389.

58 Barker, Labour in London, 104, 229.

59 The L.C.C. Hospitals: A Retrospect, 25.

60 TNA, MH 66 /1080-4, Public Health Survey Reports: Metropolitan Boroughs; Medical Officer of Health Annual Reports, available at http:/ / wellcomelibrary.org/moh/.

61 Levene, 'Between less eligibility and the NHS'.

62 TNA, MH 66/1081, Public Health Survey Report for Chelsea Metropolitan Borough; MH 66/1082, Public Health Survey Report for Hampstead Metropolitan Borough. 
Table 1: Public health expenditure, London metropolitan boroughs, London County Council and London voluntary hospitals, 1931-32

\begin{tabular}{llll}
\hline \hline & MBCs & LCC & VOL \\
\hline Environmental & $1,509,446$ & 706,024 & \\
Amenities & $1,055,215$ & 309,844 & \\
Clinical and preventive & 848,639 & $7,023,230$ & $3,485,742$ \\
Total public health & $3,413,300$ & $8,039,098$ & $3,485,742$ \\
\hline \hline
\end{tabular}

Sources: MBs: LGFS; LCC: London County Council, Accounts in Abstract 1931-32 (London, 1932), 42-3, 80-3; Administrative County of London, Financial Abstract 1925-26 to 1934-35 (London, 1936), 32-5; King Edward's Hospital Fund for London, Statistical Summary for the Year 1931 (London, 1932), 46-7.

'public authorities' have been subtracted. We can see that while the MBCs spent twice as much as the LCC on environmental health (drainage, sewerage and refuse), and over three times as much on amenities (parks and open spaces), their contribution to clinical public health and prevention was dwarfed by the LCC's budget. This was composed of its SMS (14 per cent), general hospitals (31 per cent), special and isolation hospitals (20 per cent), mental health services and institutions (26 per cent) and venereal disease and blind persons services ( 3 per cent); also included is public assistance institutions spending on the LCC's hospital account (6 per cent), which may also include some social care. Overall, the dominance of the LCC and the voluntary sector as providers of clinical or preventive services is clear.

In short, the MBCs were only one among a plethora of actors in local health care, and this places obvious limits on any conclusions which may be drawn about their impact. Nonetheless, their environmental, preventive and curative powers were not negligible, and they offered a source of democratic participation in health policy. It is therefore worth learning more about their activities.

\section{Metropolitan geographies of health and wealth}

As a preliminary exercise, it is helpful to view the main trends in population health for the whole city. Figure 1 shows London's annual crude death rate (CDR), that is deaths from all causes per 1,000 living, and the infant mortality rate (IMR), that is deaths of infants under one year per 1,000 live births. Trendlines are added to clarify the direction of change during the inter-war period. These suggest a fairly marked improvement in infant mortality, widely regarded as a sensitive gauge of general health and potentially indicative of public policy impacts. The overall mortality rate shows a less distinct improvement, with the period trend influenced by 


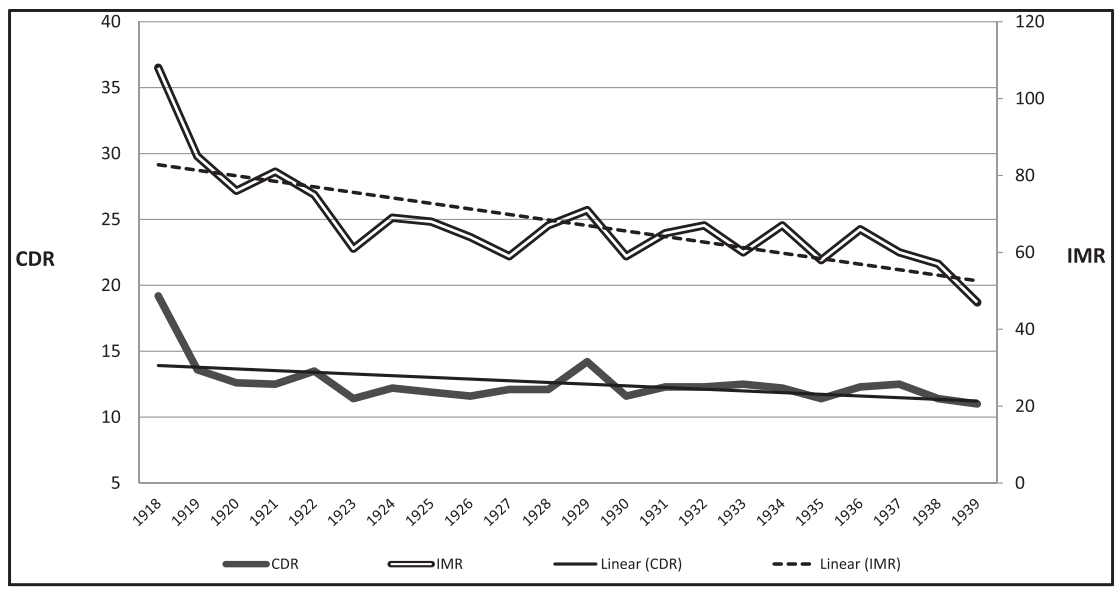

Figure 1: County of London, crude death rates and infant mortality rates, 1918-39

Source: Report of the Medical Officer of Health for London County Council, 1922, 4-5; 1935, 32; 1938, 18; 1940, 2.

the fall in 1918-21, following the influenza pandemic and recovery from war. Through the rest of the 1920s and 1930s, the CDR remained broadly stable, with peaks in 1922, 1929 and 1936-37, some of which coincided with upswings in infant mortality. On balance, all this suggests a phase of steady improvement.

However, recent calculations by Pritchard of past standardized mortality ratios (SMRs) in British local government areas modify this view for the worse. SMRs are a measure of the mortality rate in each borough, but adjusted to take account of the age structure of its population, and this permits comparison between local experience and the national trend. Figure 2 presents the SMRs for the London boroughs in the early 1920s and the later 1930s, with the gradient according to their 1930s ranking. Here, the norm for Britain is 100 (the horizontal arrow), and bars above this indicate a mortality rate higher than that of the national population. We can see that in the early 1920s, 15 boroughs had an SMR above the national rate, but that by the late 1930s, 25 were in this category. Of these, 11 in the 1920s and 15 in the 1930s were also at or above the London mean (104, 114 respectively), with boroughs such as Bermondsey, Finsbury, Shoreditch, Bethnal Green, Southwark and Stepney prominent in both periods. In sum, London's health improvements lagged behind those of Britain as a whole, markedly so in some boroughs, and they fell further back during the $1930 \mathrm{~s} .{ }^{63}$ The

63 J. Pritchard, 'Mortality mosaics: measuring and mapping mortality patterns in Britain 1921-2005', University of Southampton M.Sc. dissertation, 2008, 33-4. 


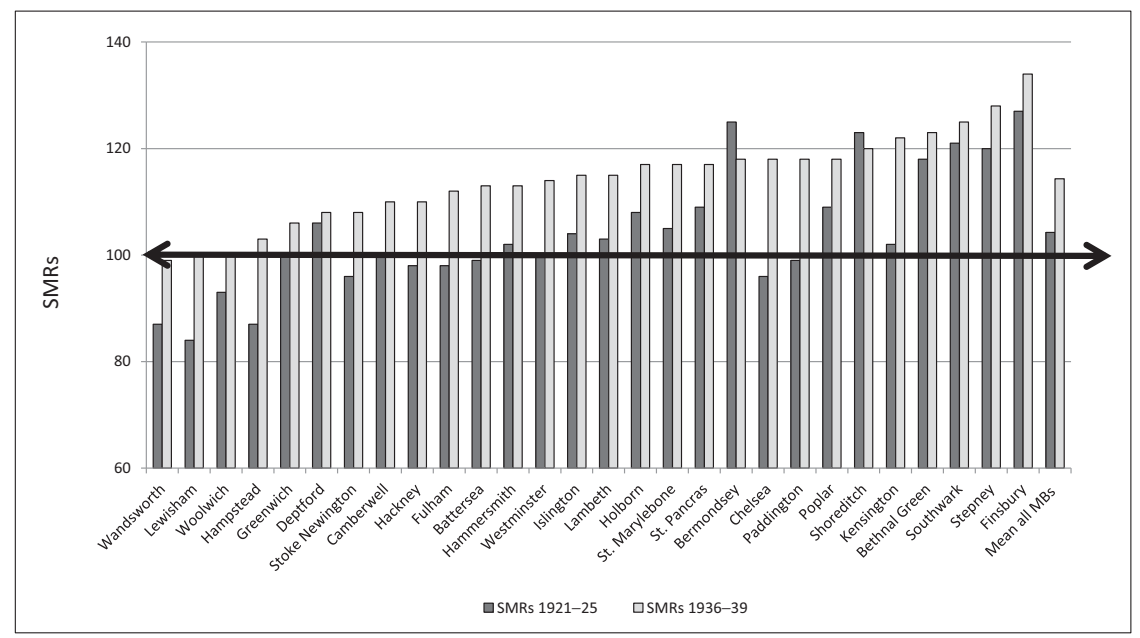

Figure 2: London metropolitan boroughs, standardized mortality ratios, $1921-25$ and 1936-39 $($ Britain $=100)$

Source: J. Pritchard, 'Mortality mosaics: measuring and mapping mortality patterns in Britain 1921-2005', University of Southampton M.Sc. dissertation, 2008, 40.

standard deviation around the mean of all boroughs fell slightly from 11.26 to 8.24 , but this narrowing of disparities hardly ameliorated the situation.

To develop this picture we may consider variations in IMRs between the boroughs. Figure 3 presents these for two periods in the 1920s and 1930s, with the gradient again following the SMR rankings for the 1930s, shown in Figure 2. We can see that most boroughs shared the city's general experience of falling infant mortality rates, though a few bucked this trend: Hampstead, Battersea, Westminster, Kensington and Finsbury. Other places, such as Greenwich, Fulham, Bermondsey and Shoreditch, experienced large declines and again this raises questions about policy effects. Crude visual comparison of the gradients in the two charts underlines the importance of infant mortality in determining a borough's SMR, although the relationship was not always close, for example in the cases of Stoke Newington, Holborn and Chelsea in the 1930s. Above all though, Figures 2 and 3 illustrate considerable variation in population health between London's boroughs.

Writing in 2000, Dorling and others observed that such enduring patterns of health inequality in London corresponded closely with the spatial incidence of deprivation, just as they had 100 years earlier. ${ }^{64}$ Given this apparently persistent association it is useful next to consider the

64 D. Dorling, R. Mitchell, M. Shaw, S. Orford and G. Davey Smith, 'The ghost of Christmas past: health effects of poverty in London in 1896 and 1991', BMJ, 321 (2000), 1547-51. 


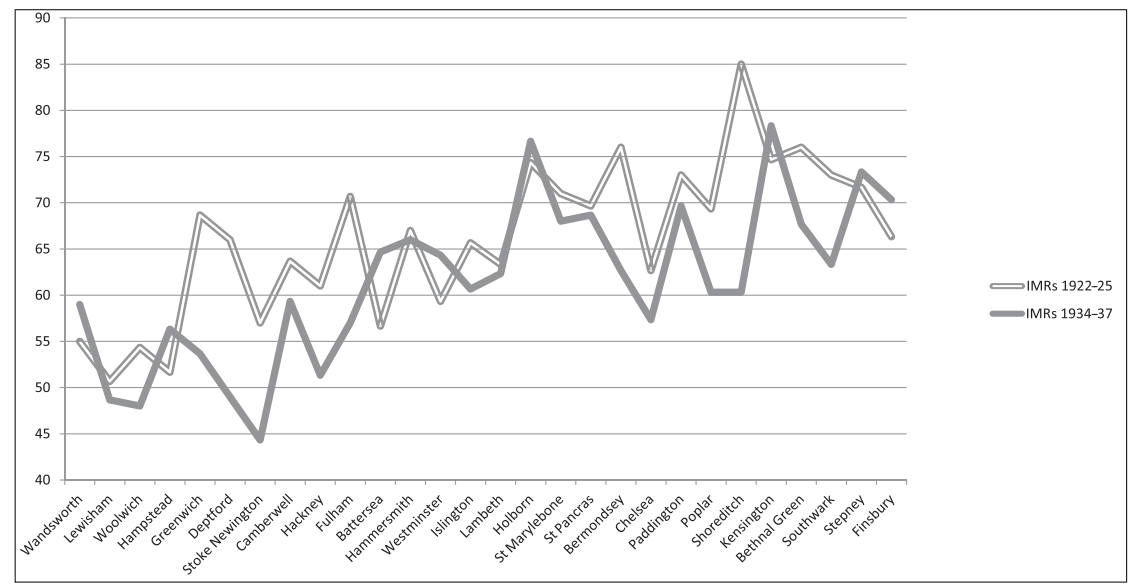

Figure 3: London metropolitan boroughs, infant mortality rates, 1922-24 and 1933-37

Source: Registrar-General's Annual Reports.

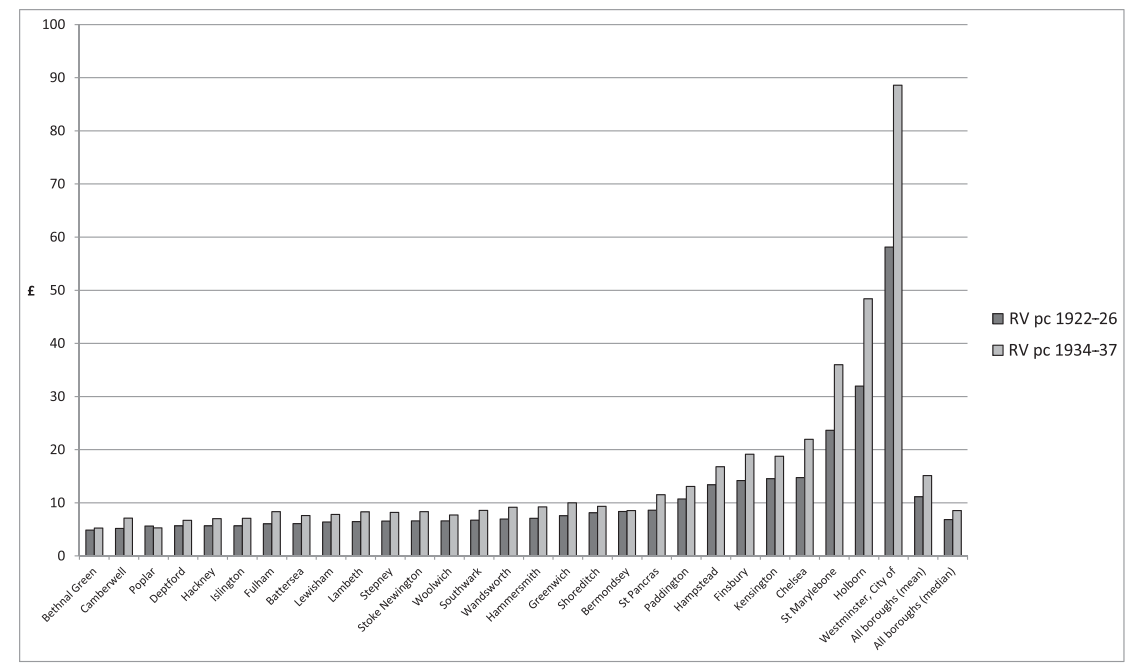

Figure 4: London metropolitan boroughs, rateable value per capita, mean 1922/23-1925/26, 1934/35-1936/37

Source: LGFS (previously LTR).

inter-war distribution of wealth. A standard indicator of a borough's prosperity is its rateable value, here shown (Figure 4) per capita for two phases, the early 1920s and the mid-1930s. Change between the periods relates to alterations in the procedure of rating; this included acts of 1925 
and 1928 which changed valuation methods. ${ }^{65}$ It should also be noted that an Equalization of the Rates Fund obtained between 1894 and 1929, through which the LCC made compensatory grants from rich to poor boroughs, and there was also a Common Poor Fund, operational between 1867 and 1929, used to redistribute Poor Law costs. Thus, rateable value alone misrepresents actual financial capacity, though only to a degree: the former arrangement effected only a modest redistribution, while the latter was increasingly limited in its remit as local maintenance costs outstripped the sums available under equalization arrangements. ${ }^{66}$

The gradient on the chart is based on the ranking of the 1920s data, but it will be observed that the pattern remains fairly similar across the two periods. The extremes also remained constant, with Bethnal Green in the East End the poorest $(4.88,5.25)$ and Westminster the most prosperous $(58.12,88.60)$. The mean for all boroughs is 11.14 rising to 15.14 , and alongside these increasing values was a widening of the standard deviation, from 11.02 to 17.28: differences grew greater, not narrower, in the depressed 1930s. Visual comparison of Figures 3 and 4 reveals no overt correlation: richer boroughs (Finsbury) could experience high IMRs, alongside poorer ones (Bethnal Green), while moderately rated boroughs (Stoke Newington) could enjoy health gains.

\section{Health and London party politics}

In light of this, we may hypothesize instead that local democracy exerted some influence on change or stasis in health outcomes. As noted above, previous research has shown that Labour party strength on provincial councils was associated with active approaches to maternal and child health, and more indirectly with reformist hospital policy. ${ }^{67}$ Party presence is therefore a useful measure, though the existence of unitary platforms should not be assumed. Local government conservatism for example accommodated traditionalists, ratepayer lobbies and progressives, while metropolitan socialism was sometimes bitterly divided, between borough parties seeking autonomy in welfare policy and advocates of disciplined centrism, typified by Herbert Morrison, leader of the London Labour party. ${ }^{68}$ Moreover, qualitative studies have shown that party interests

65 H. Finer, English Local Government, 3rd edn (London, 1946), 498.

66 Ibid., 500-2; White, London in the Twentieth Century, 361; Gibbon and Bell, History of the London County Council, 405; after the Poplar revolt of 1921, the Common Poor Fund did meet some $85 \%$ of the cost of unemployment relief, J. Gillespie, 'Poplarism and proletarianism: unemployment and Labour politics in London, 1918-34', in D. Feldman and G. Stedman Jones (ed.), Metropolis - London: Histories and Representations since 1800 (London and New York, 1989), 163-88, at 180.

67 Powell, 'Did politics matter?'; Neville, 'Explaining local authority choices'.

68 Neville, 'Explaining local authority choices', 55-6; S.V. Ward, The Geography of Interwar Britain (London, 1988); M. Clapson, 'Localism, the London Labour Party and the LCC between the wars', in Saint (ed.), Politics and the People of London, 127-45; N. Branson, Poplarism, 1919-1925. George Lansbury and the Councillors' Revolt (London, 1979), 160-70. 
could be less important in effecting change than incremental factors or the presence of 'policy entrepreneurs' ${ }^{69}$

All that said, inter-war London's political history is dominated by the rise of Labour. ${ }^{70}$ The creation of the LCC had 'injected party politics into London government', and the century opened with an expansion of municipal activity by the LCC driven by Progressives (a grouping that included Radical Liberals and socialists like John Burns and Sidney Webb). ${ }^{71}$ This galvanized Conservative partisanship in response, first as the Moderates, championing retrenchment in 1889, then, from 1918, as the Municipal Reform party. After the war, the increasing mobilization of trade unions, the support of the Fabians and the Democratic Federation and growth of local Labour parties (notably in West Ham, Woolwich and Poplar) heralded a breakthrough in 1919, when Labour won a foothold in the LCC and took control of 12 MBCs. ${ }^{72}$ By 1925, the Progressives, and thus Liberal influence, had disappeared and two-party politics dominated.

What did this mean for health and welfare? Put crudely, the Municipal Reform platform was built on responsible stewardship of sanitary provision and pragmatic housing development (for which their LCC record was strong), while repudiating recklessness and extravagance on the rates. ${ }^{73}$ Labour meanwhile had from its early years advocated active public health policies with a deliberate appeal to voters. New baths and washhouses would enhance the hygiene and comfort of people whose houses lacked amenities, the health of mothers and children would be improved by pre- and ante-natal medical care, by midwife attendance at childbirth and by safe milk depots, and council services would be underpinned with pay improvements for staff. This package addressed the interests of newly enfranchised women voters, and met grassroots concerns of groups such as the Women's Co-operative Guild that constituted Labour's organizational base. ${ }^{74}$

The 1920s were years of Municipal Reform dominance of the LCC and boroughs, and of mixed fortunes for Labour following 'direct action' by the left in defence of the jobless. This climaxed in the celebrated Poplar episode, when socialist councillors were imprisoned for refusing

${ }^{69}$ Neville, 'Explaining local authority choices', 67-70; the concept derives from US political scientists: J. Kingdon, Agendas, Alternatives and Public Policies (New York, 1995), 179-83.

70 White, London in the Twentieth Century, 355-76.

${ }^{71}$ Davis, Reforming London, 115; J. Davis, 'The Progressive Council, 1889-1907', in Saint (ed.), Politics and the People of London, 27-48; K. Young, Local Politics and the Rise of Party: The London Municipal Society and the Conservative Intervention in Local Elections (Leicester, 1975), 78-9; Davis, Reforming London, 248-54.

72 P. Thompson, Socialists, Liberals and Labour. The Struggle for London 1885-1914 (London, 1967), 296; White, London in the Twentieth Century, 366; J. Marriott, The Culture of Labourism. The East End between the Wars (Edinburgh, 1991), 68-121.

73 Marriott, Culture of Labourism, 54-5; R. Porter, London: A Social History (London, 1994), 408-9.

74 Thompson, Socialists, Liberals and Labour, 184, 232, 258-9; Branson, Poplarism, 22, 41, 162; Marriott, Culture of Labourism, 37, 49-53. 


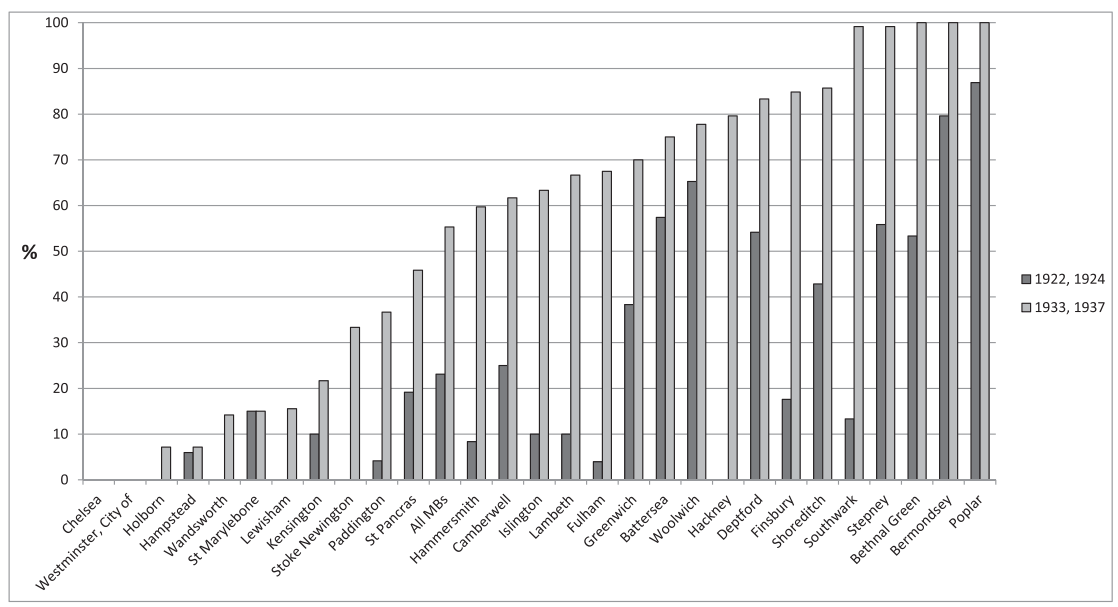

Figure 5: London metropolitan boroughs, percentage of Labour party seats won in borough elections, means of 1922/25 and 1933/37 Source: Willis and Woollard, 20th Century Local Election Results, vol. I: Election Results for the London County Council (1889-1961) and London Metropolitan Boroughs (1900-1928), vol. II: Election Results for London Metropolitan Boroughs (1931-1962).

to remit the borough rate precept due to the LCC, the Metropolitan Police and the $\mathrm{MAB}$, the better to maintain generous levels of poor relief for the local unemployed and decent pay for their own staff. ${ }^{75}$ Poplar's subsequent victory in obtaining more just equalization of Poor Law funding was muted by electoral losses elsewhere in 1922, as Municipal Reform candidates profited from an anti-socialist backlash. ${ }^{76}$ The early 1930s saw Labour's gradual recovery in the capital, despite its having ceded national power during the economic crisis. Victory in the LCC elections of 1934 marked a decisive turning point. The components of its success were its record on housing, its appeal to women voters, the demonstration effect of boroughs like Bermondsey with innovative public health policies and Morrison's determined struggle to convince voters of Labour's constitutionalist credentials; indirectly, it also benefited from the flight of the middle classes to the suburbs. ${ }^{77}$

Figure 5 shows this swing to the Labour party during the inter-war years, represented by the mean percentage of seats won across four elections in the 1920s and 1930s. ${ }^{78}$ It demonstrates how the political complexion of

75 Branson, Poplarism; Gillespie, ‘Poplarism'; Marriott, Culture of Labourism, 122-62.

76 Young, Local Politics, 121-2; Branson, Poplarism, 131-5, 160-1.

77 Porter, London, 371-7.

${ }^{78}$ Finer, English Local Government, 492; numbers of borough councillors varied according to population, and all seats were contested at triennial elections, though aldermen elected by councillors for a six-year term took one sixth of the council places. 
the boroughs varied significantly across time and place, with the gradient here according to the rankings for the 1930s data. In the 1920s elections, Labour's presence was far from dominant: it exceeded 50 per cent of votes won in only 7 of the 28 boroughs, with Woolwich, Bermondsey and Poplar the obvious strongholds. By the 1930s, the situation was very different, with Labour now winning 60 per cent of contested seats in 17 boroughs, including clean sweeps in 3: Bethnal Green, Bermondsey and Poplar. Visual comparison with Figure 4 reveals some correspondence with the wealth rankings, in that in the 1930s almost all strong Labour boroughs, with the exception of Finsbury, were well below the mean rateable value, and several somewhat below the median (for example Deptford, Hackney, Woolwich, Battersea, Islington, Poplar, Camberwell and Bethnal Green). By the same token, the Municipal Reform party retained its strength in London's prosperous boroughs such as Hampstead, Kensington, Marylebone and Holborn, and most notably Chelsea and Westminster, where Labour took no seats at all. Thus, unsurprisingly, Labour's constituency was the lower-income, working-class voter, and it seems plausible that policies towards welfare and health, epitomized by Poplarism and the LCC's hospital programme, accentuated its municipal appeal.

\section{Public health in the metropolitan boroughs}

Coming now to the public health work of the MBCs, Figure 6 shows the main components of expenditure in the mid-1930s, the period between the slump and the Second World War which saw the 'zenith' of municipalism. ${ }^{79}$ The gradient in the graph is according to the rankings of total public health expenditure, excluding housing. To illustrate change over time, the total per capita public health and housing expenditure from the mid-1920s is also shown, at current prices.

With the limits of the MBCs' remit (Table 1) in mind, what do the financial data show? Public health expenditure increased in almost all boroughs during this period with the exception of Hampstead. Secondly, while there was some correspondence between willingness to spend on housing and on public health, other boroughs bucked this trend, with comparatively larger housing budgets (Hammersmith, Greenwich, Woolwich), or smaller ones (Marylebone, Holborn, Southwark). Thirdly, visual inspection does not immediately suggest an overt relationship between levels of health and welfare expenditure and underlying wealth or political complexion. High-spenders could be prosperous and Municipal Reform-led, like Westminster, or Labour heartlands like Bermondsey

${ }^{79}$ Readers interested in comparing spending levels in the provincial county boroughs should consult Table 3 in Levene, Powell and Stewart, 'Investment choices?', 448-50; though reported as '1936', these data appear to be for the 1936/37 financial year so are only approximately comparable. 


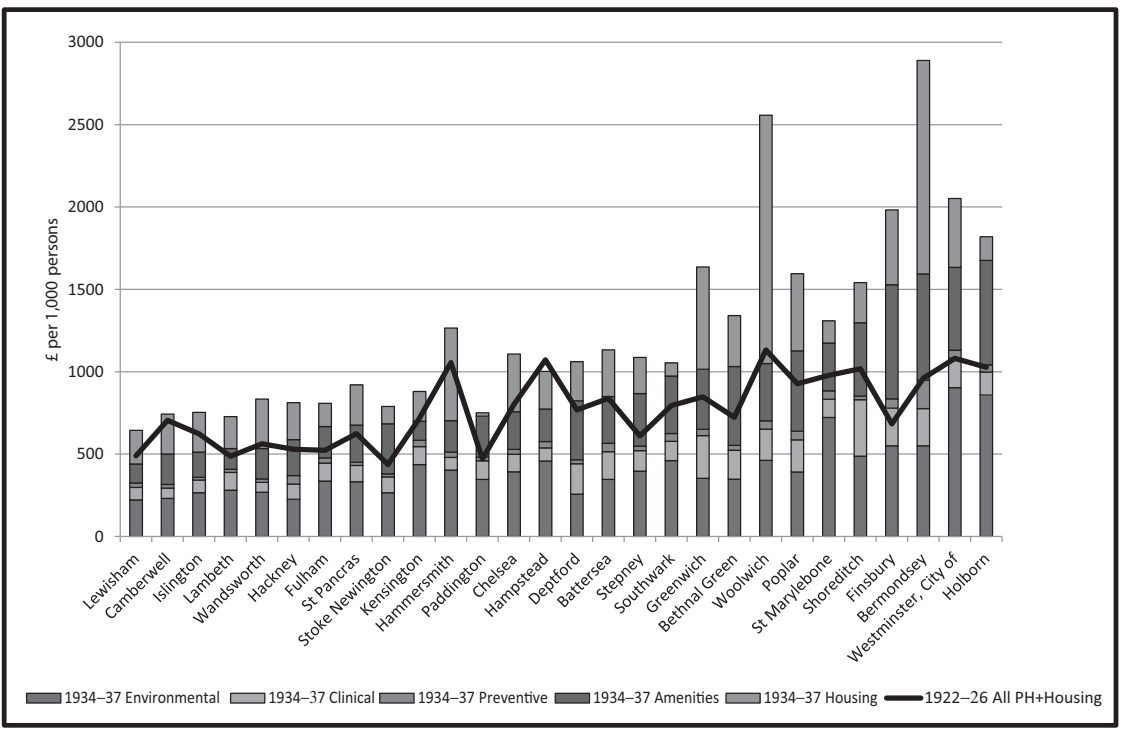

Figure 6: London metropolitan boroughs, composition of per capita expenditure on housing and public health, 1934-37

Source: LGFS (previously LTR).

and Woolwich. Applying this broad definition of public health activity, however, may not be the best route to exploring its relationship with contextual factors of wealth or party politics.

An alternative approach is to extract and disaggregate the clinical and preventive elements of health department activities, and these are shown separately in Figure 7, again expressed per capita. Although these formed only a small part of total public health expenditure, they represented areas in which boroughs could intercede to achieve some direct impacts on morbidity and mortality. These included spending on institutional and dispensary care for tuberculosis, maternity and child welfare, notification of infectious diseases, disinfection interventions, vaccination and controls on food and drug safety. Once again, the 1922-26 period is shown for comparison, while the gradient of the graph follows borough rankings for 1934-37.

Again, all boroughs increased expenditure in these areas between the two periods, with some, notably Finsbury, Westminster and Paddington, moving up the rankings: of these, Finsbury had shifted strongly to Labour in the intervening years, Paddington rather less so and Westminster not at all. Apart from Westminster, the high-spenders tended to be boroughs where Labour was strongest, as cross reference to Figure 5 confirms. Maternity and child health programmes were the dominant category of 


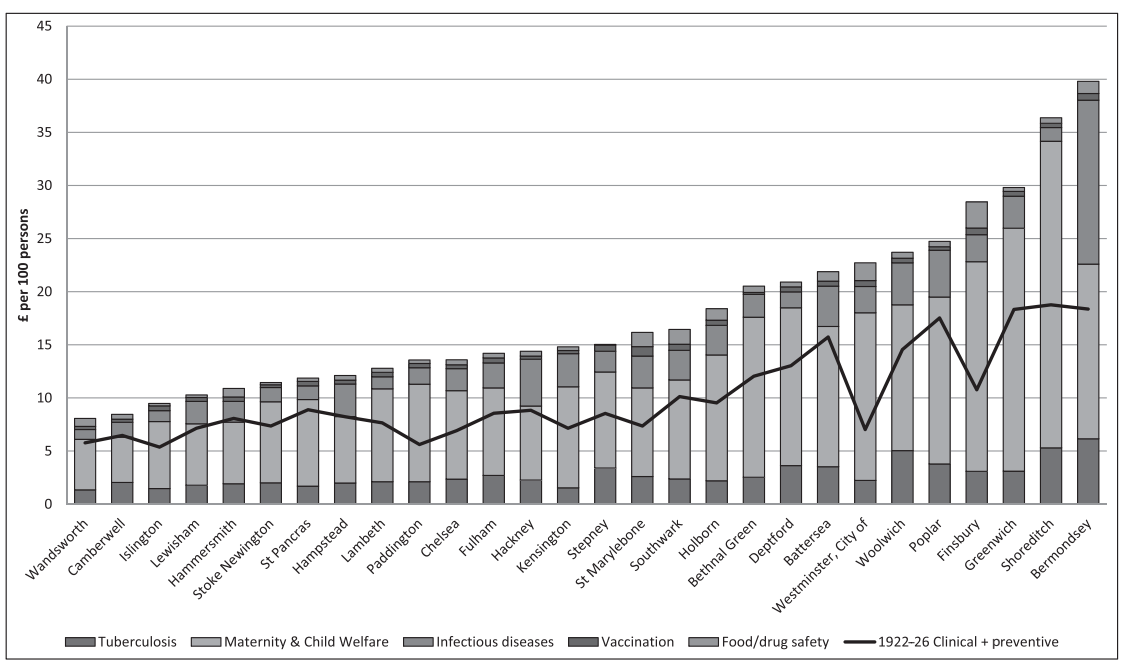

Figure 7: London metropolitan boroughs, per capita expenditure on clinical and preventive health services by category, 1934-37

Source: LGFS (previously LTR).

expenditure, perhaps reflecting a desire to reduce infant mortality rates, and to meet concerns of female voters. ${ }^{80}$ Bermondsey was distinctive in the greater proportion expended on the infectious diseases category, which may reflect the opening of a council health centre in 1936. This brought together not only facilities for $\mathrm{TB}$, child health and a post-infectious cases clinic, but also dentistry, podiatry, ante-natal care, x-rays, light therapy, ENT treatment and an unusually proactive 'health propaganda' department which produced and screened its own public information films. ${ }^{81}$

\section{Determinants and effects of MBC public health spending}

Having reviewed the range of experience across the MBCs with respect to public health effort (as gauged by spending), political complexion, underlying wealth and health outcomes, we close by asking whether there are discernible statistical relationships between these factors.

First, Table 2 presents a correlation matrix exploring relations between the variables in the mid-1930s, showing the different elements of spending. The 'total public health expenditure' category is exclusive of housing,

80 See J. Lewis, The Politics of Motherhood: Child and Maternal Welfare in England, 1900-1939 (London, 1980).

81 F. Brockway, Bermondsey Story. The Life of Alfred Salter (London, 1995; orig. edn 1949); Lebas, "When every street became a cinema". 
Table 2: Correlation coefficients between selected per capita expenditure, political and population data, 28 London metropolitan boroughs, 1934/35-1936/37

\begin{tabular}{|c|c|c|c|c|c|c|c|c|c|c|c|c|c|}
\hline & RV & ENV & $\mathrm{TB}$ & MCW & CLIN & PREV & AME & PHTOT & $\mathrm{HOU}$ & EXPTOT & LAB & CDR & IMR \\
\hline RV & 1.00 & & & & & & & & & & & & \\
\hline ENV & 0.84 & 1.00 & & & & & & & & & & & \\
\hline $\mathrm{TB}$ & -0.16 & 0.19 & 1.00 & & & & & & & & & & \\
\hline MCW & 0.11 & 0.34 & 0.72 & 1.00 & & & & & & & & & \\
\hline CLIN & 0.07 & 0.33 & 0.80 & 0.99 & 1.00 & & & & & & & & \\
\hline PREV & 0.08 & 0.37 & 0.64 & 0.27 & 0.35 & 1.00 & & & & & & & \\
\hline AME & 0.34 & 0.62 & 0.61 & 0.69 & 0.70 & 0.55 & 1.00 & & & & & & \\
\hline PHTOT & 0.56 & 0.85 & 0.58 & 0.70 & 0.71 & 0.55 & 0.92 & 1.00 & & & & & \\
\hline HOU & -0.07 & 0.16 & 0.58 & 0.33 & 0.41 & 0.63 & 0.37 & 0.35 & 1.00 & & & & \\
\hline EXPTOT & 0.99 & 0.89 & -0.05 & 0.19 & 0.15 & 0.18 & 0.44 & 0.66 & 0.04 & 1.00 & & & \\
\hline LAB & -0.59 & -0.32 & 0.57 & 0.37 & 0.42 & 0.26 & 0.30 & 0.09 & 0.29 & -0.53 & 1.00 & & \\
\hline CDR & 0.00 & 0.12 & -0.01 & 0.03 & 0.01 & 0.05 & 0.11 & 0.12 & -0.25 & -0.01 & 0.08 & 1.00 & \\
\hline IMR & 0.32 & 0.48 & -0.09 & 0.04 & 0.01 & 0.09 & 0.24 & 0.34 & -0.22 & 0.33 & -0.07 & 0.55 & 1.00 \\
\hline
\end{tabular}

Probability level: $.05=.32 ; .025=.37 ; 0.1=44 ; .005=.48 ; .0005=59$

KEY:

RV: rateable value; ENV: environmental; TB: tuberculosis; MCW: maternity and child welfare; CLIN: total clinical health services; PREV: preventive; AME: amenities; PHTOT: total public health expenditure; HOU: housing; EXPTOT: total rate-borne expenditure: LAB: \% Labour seats over 2 elections; CDR: crude death rate; IMR: infant mortality rate

All financial data: mean annual expenditure, 1922/23-1925/26, per thousand population.

Sources: LGFS / LTR (all expenditures); Willis and Woollard, 20th Century Local Election Results, vol. I: Election Results for the London County Council (1889-1961) and London Metropolitan Boroughs (1900-1928), vol. II: Election Results for London Metropolitan Boroughs (1931-1962) (election results); Registrar-General's Annual Reports (CDR, IMR). 
which is treated separately, and an additional category of 'total rateborne expenditure' is also shown, which includes health alongside all the other components of borough activity. The figures shown in bold indicate correlation coefficients that are sufficiently strong to indicate a statistically significant relationship between the variables, which may merit further analysis.

Considering first the importance of wealth, there is a predictable relationship between rateable value and total rate-borne expenditure, confirming that underlying prosperity was an essential determinant of capacity (albeit with the two London equalization mechanisms and, after 1929, the central government block grant calculated by a weighted population formula, ensuring a degree of redistribution). ${ }^{82}$ There is a close fit too between wealth and level of environmental spending, and a weaker correlation with total public health expenditure. Finally, a significant negative relationship obtains between the rich boroughs and proportion of the Labour vote, confirming the impression given by Figure 5 . There is a positive relationship between Labour strength and clinical public health spending, though this is stronger for TB initiatives (0.57) than for maternal and child health (0.37), and both are weaker than for the 1920s, when the same coefficients were 0.71 and 0.65 respectively (1922-26). Within the various categories of public health spending there are some observable correlations, so that, for example, places that spent high on amenities also had generous levels of clinical and preventive expenditure. There are no relationships evident between the population health indicators and other variables, apart from a positive one between the IMR and level of environmental spending, and this may indicate the importance of sanitation and domestic hygiene, even into the mid-twentieth century.

A simple correlation analysis therefore suggests that in these three years poorer boroughs tended towards Labour representation and that socialist influence was weakly associated with higher clinical public health spending. However, neither party, nor wealth, nor the preventive and curative initiatives correlate with health outcomes. Possibly these are better explained by other variables not captured here, such as LCC programmes, or medical charities, or factors such as real wage levels or improved diets. Or it may be that cross-sectional correlation misses temporal effects. To explore the latter issue we turn finally to regression analysis, considering first the relationship between votes for Labour and public health effort.

Where relationships between the percentage of Labour seats and various expenditure measures were broadly linear, a linear regression analysis was run to quantify associations during the two periods 1922-26 and 193437. Table 3 shows that during 1922-26, for each 1 per cent increase in Labour seats across the boroughs, there was an additional $£ 1.90$ increase in total public health $(\mathrm{PH})$ expenditure per 1,000 population. However,

82 B. Preston, 'Rich town, poor town: the distribution of rate-borne spending levels in the Edwardian city system', Transactions of the Institute of British Geographers, 10 (1985), 77-94. 
Table 3: Effect of percentage of Labour seats on expenditure

\begin{tabular}{|c|c|c|c|c|c|c|}
\hline \multirow[b]{2}{*}{ Outcome: } & \multicolumn{3}{|c|}{ Crude model } & \multicolumn{3}{|c|}{ Adjusted model* } \\
\hline & Coefficient $(95 \% \mathrm{CI})$ & P-value & R-squared (\%) & Coefficient $(95 \% \mathrm{CI})$ & P-value & R-squared (\%) \\
\hline \multicolumn{7}{|l|}{$1922-26$} \\
\hline Total PH exp/1,000 (£) & $1.90(-0.97,4.78)$ & 0.19 & 6.67 & $3.87(1.96,5.79)$ & $<0.001$ & 66.89 \\
\hline TB spend $/ 1,000(£)$ & $0.15(0.09,0.21)$ & $<0.001$ & 50.03 & $0.16(0.09,0.23)$ & $<0.001$ & 51.60 \\
\hline $\mathrm{M} \& \mathrm{CW}$ spend $/ 1,000(£)$ & $0.81(0.43,1.19)$ & $<0.001$ & 42.31 & $0.74(0.33,1.15)$ & 0.001 & 45.64 \\
\hline Total personal $(£)$ & $0.97(0.60,1.34)$ & $<0.001$ & 52.56 & $0.91(0.50,1.31)$ & $<0.001$ & 55.22 \\
\hline Total preventive $(£)$ & $0.29(0.12,0.46)$ & 0.002 & 32.07 & $0.35(0.18,0.52)$ & $<0.001$ & 43.95 \\
\hline Total amenities $(£)$ & $0.83(-0.57,2.23)$ & 0.23 & 5.39 & $1.52(0.25,2.79)$ & 0.02 & 38.07 \\
\hline \multicolumn{7}{|l|}{$1934-37$} \\
\hline Total PH exp/1,000 (£) & $1.03(-3.51,5.58)$ & 0.65 & 0.83 & $6.35(2.69,10.02)$ & 0.002 & 65.60 \\
\hline TB spend $/ 1,000(£)$ & $0.19(0.08,0.30)$ & 0.002 & 32.41 & $0.19(0.07,0.32)$ & 0.004 & 53.70 \\
\hline M\&CW spend $/ 1,000(£)$ & $0.64(-0.00,1.28)$ & 0.05 & 13.81 & $1.04(0.27,1.81)$ & 0.01 & 33.86 \\
\hline Total personal $(£)$ & $0.84(0.11,1.56)$ & 0.03 & 17.82 & $1.22(0.36,2.07)$ & 0.007 & 39.42 \\
\hline Total preventive $(£)$ & $0.22(-0.12,0.55)$ & 0.19 & 6.52 & $0.21(-0.14,0.57)$ & 0.23 & 44.18 \\
\hline Total amenities $(£)$ & $1.43(-0.43,3.29)$ & 0.13 & 8.71 & $3.29(1.47,5.10)$ & 0.001 & 53.63 \\
\hline
\end{tabular}

* Adjusted for rateable value per head and total housing spend per 1,000 population.

Sources: LGFS/LTR (expenditures); Willis and Woollard, 20th Century Local Election Results, vol. I: Election Results for the London County Council (1889-1961) and London Metropolitan Boroughs (1900-1928), vol. II: Election Results for London Metropolitan Boroughs (1931-1962) (election results). 
after adjusting for expenditure measures likely to benefit all residents regardless of wealth - namely rateable value per head (RV) and housing expenditure - the Labour effect more than doubled to $£ 3.87 \mathrm{PH}$ spend per thousand people for each additional percentage point of Labour seats. This increase was highly statistically significant $(\mathrm{P}<0.001)$. During 193437 , the Labour effect was even more pronounced on total PH expenditure: $£ 6.35$ for each additional percentage point after adjustment. Increased percentage of Labour seats was also associated with more specific $\mathrm{PH}$ factors, i.e. TB and maternity and child welfare, as well as total clinical, preventive and amenities expenditure. However, in most cases the amount of variation in the spending measure being explained by the combined predictive power of percentage Labour seats, RV and housing expenditure was less than 50 per cent (R-squared values in table). This indicates again that other factors we could not incorporate in the analysis, such as the role of the LCC and the medical charities, may explain much of the pattern of health expenditure.

To address the question of whether $\mathrm{PH}$ expenditure led to improvements in outcomes such as reduced IMR, further regression analysis was conducted on the time-series of annual IMR in relation to annual percentage of $\mathrm{PH}$ expenditure. Since, in many boroughs, reductions in IMR during the inter-war years coincided with increased $\mathrm{PH}$ expenditure, simply correlating the two annual measures would indicate a strong negative association. However, this is unlikely to be causal since many factors will have been responsible for the secular trends observed in IMR during this period. So for each borough, a regression model was developed which controlled for underlying trends in IMR and then any remaining association with annual PH spend was assessed.

Table 4 presents the associations between percentage $\mathrm{PH}$ spend and both IMR and CDR after controlling for underlying trends. The results are combined for all boroughs using a random-effects meta-analysis. A linear relationship was assumed between exposure and outcome and a distributed lag model used, i.e. one that assesses effects of expenditure on IMR and CDR in the same year as expenditure, but also in subsequent years to assess delayed effects. This shows a general pattern of decreased IMR and CDR as the percentage of PH spend increases. The effect was stronger on IMR than CDR, and the biggest impact on IMR was observed in the same year as the year of expenditure (lag 0) with also a substantial impact two years later (lag 2), although curiously the impact on the intervening year was not as strong or statistically significant (lag 1). The influence of $\mathrm{PH}$ spending on IMR was revealed to be much greater once RV had been adjusted for. After adjustment, every 1 per cent increase in $\mathrm{PH}$ spending as a proportion of total spend led to a 9.23 per cent reduction in IMR in the expenditure year, as well as reductions in the following two years.

Regression analysis therefore suggests two conclusions. First, in areas where Labour achieved electoral success there was observably heightened 
Table 4: Change (95\% CI) in outcome for every 1\% increase in PH spend as a proportion of total spend

\begin{tabular}{llcrlr}
\hline & \multicolumn{2}{c}{ Infant mortality rate (IMR) } & & \multicolumn{2}{c}{ Crude death rate (CDR) } \\
\cline { 2 - 3 } & Unadjusted model & Model adjusted for RVPH & & Unadjusted model & Model adjusted for RVPH \\
\hline Lag 0 & $-4.26(-6.64,-1.87)$ & $-9.23(-18.04,-0.43)$ & & $-0.76(-1.31,-0.20)$ & $-0.38(-1.12,0.36)$ \\
Lag 1 & $-0.40(-2.51,1.71)$ & $-5.27(-12.43,1.88)$ & & $-0.87(-1.46,-0.29)$ & $-0.52(-1.37,0.33)$ \\
Lag 2 & $-2.64(-4.51,-0.77)$ & $-7.09(-13.43,-0.74)$ & & $-0.29(-0.77,0.19)$ & $-0.69(-1.16,-0.21)$ \\
Lag 3 & $1.24(-1.94,4.42)$ & $1.02(-7.41,9.45)$ & & $-0.56(-1.30,0.17)$ & $-0.64(-1.42,0.13)$ \\
\hline \hline
\end{tabular}

Sources: Registrar-General's Annual Reports (CDR, IMR); LGFS/LTR (expenditures). 
expenditure, and by implication policy focus, on public health. And second, MBCs committing more to public health expenditure did see better health outcomes, as reflected in improvement to the IMR.

\section{Conclusion}

We began by characterizing the debate over the performance of public health in local government as opposing poles. One was Bevan's argument that localism militated against more equal standards of access and quality because of variations in the wealth base. The other was Morrison's view of the municipality as the better administrative site, because it preserved values of 'responsiveness... differentiation... selfgovernment' ${ }^{83}$ We sought to introduce evidence from London into this discussion, though we also stressed the particular complexities of the capital which limit the conclusions which may be drawn from analysis of the performance of the metropolitan boroughs.

Our findings were mixed. In support of Bevan's position, we showed that despite the much-vaunted comprehensiveness of LCC services, general health gains in inter-war London boroughs were comparatively slow. Health variations between boroughs were also marked, although there was some narrowing of differences through the period. However, in support of Morrison's position, we found evidence for a positive effect when considering the statistical relationships between Labour's power on MBCs and their propensity to spend on public health. This is consonant with Powell's finding that 'politics mattered' in provincial county boroughs, and also with qualitative accounts of Poplar and Bermondsey. When we considered the relationship between public health expenditure and outcomes, there did seem to be both a current and lagged effect of improvement to IMRs, albeit inconsistent.

We are reluctant to claim too much for either of these results. In addition, available borough-level variables are limited, meaning we were unable to incorporate expenditure by voluntary providers or the LCC. Nonetheless, our results are at least suggestive of local choice exercised through the ballot box leading to distinctive and potentially beneficial public health policies.

Our findings therefore align with recent literature in this field, which combines comparative quantitative analysis with accumulating casestudies, and yields supporting evidence for both poles of the debate. Such an outcome from this kind of empirical approach is not necessarily surprising. Perhaps the problem is not so much to establish whether localized health services functioned less effectively than a centralized system, as to understand how contemporaries came to believe that this was so. Are earlier historians correct to suggest a new 'sedimentary consensus'

${ }^{83}$ Klein, New Politics of the NHS, 21. 
was forming in favour of reform, incorporating a change in 'social ideas' which undermined localism ${ }^{84}$ If so, then the next task is to determine the nature and causes of this shift, not only among national policy-makers, but also amongst agents and recipients at the municipal interface.

Future qualitative work on London will be central to resolving this question. Here, the Ministry of Health could see at first hand the problems of localist health administration, such as the tensions between the MBCs and the LCC, and the removal of the SMS from the MOHs' remit. ${ }^{85}$ The extent to which exposure to metropolitan health politics sharpened contemporaries' awareness of the need to integrate local, regional and national priorities remains to be discovered. London's importance as a case-study will also grow as scholars turn their attention to the newly digitized borough $\mathrm{MOH}$ reports. ${ }^{86}$ Our findings therefore provide intriguing signposts to boroughs which most merit further consideration, as research moves from statistics of activity to textual articulations of needs and policies.

\section{Data}

All financial and other data used for the quantitative analysis in this article can be found through the LSHTM Data Compass at http:/ /dx.doi.org/10. 17037/DATA.103.

${ }^{84}$ Ibid., 12; Peacock and Wiseman, Growth of Public Expenditure, 117-20.

85 See, for example, TNA, MH 66/1080, Health Survey Report for the London County Council, 6, 114-17; TNA, MH 66/1081, Health Survey Report for Chelsea, 13; TNA MH 66/1082, Health Survey Report for Islington, 11.

${ }^{86}$ Text mining research with these reports will constitute the basis of a future article. 